\title{
SEROPREVALENCE OF CANINE MONOCYTIC EHRLICHIOSIS IN HUNTING DOGS IN THE AUTONOMOUS PROVINCE OF VOJVODINA, SERBIA
}

\author{
Aleksandar Potkonjak ${ }^{1 *}$, Sara Savić ${ }^{2}$, Ljubica Spasojević Kosić ${ }^{1}$, Vuk Vračar ${ }^{1}$, \\ Radmila Kudus ${ }^{1}$, Ljiljana Suvajdžić ${ }^{3}$,Nenad Radišić ${ }^{1}$ \\ ${ }^{1}$ University of Novi Sad, Faculty of Agriculture, \\ Department of Veterinary Medicine, Novi Sad, Serbia \\ ${ }^{2}$ Scientific Veterinary Institute „Novi Sad“, Novi Sad, Serbia \\ ${ }^{3}$ Medical Faculty, Department of Pharmacy, Novi Sad, Serbia
}

\section{Abstract}

Canine monocytic ehrlichiosis is a bacterial, vector-transmitted infection caused by Ehrlichia canis. The pathogen is mainly transmitted by ticks Rhipicephalus sanguineus. The disease highest distributionis most widely distributed in tropical and subtropical countries but it is also reported in Mediterranean countries of Europe (Spain, France, Italy, Turkey). Temperate continental climate and presence of these tick species are responsible for the maintenance and spreading of canine monocytic ehrlichiosis within the dog population in our region as well. Since hunting dogs are more exposed to tick bites then pet dogs, ed thisour study was conducted with the aims of determining the seroprevalence and basic epidemiological characteristics of monocytic ehrlichiosis infection in the population of hunting dogs, and comparing the obtained results with the results of other authors. This research involved 58 hunting dogs from the region of Autonomous Province of Vojvodina. All dogs were clinically examined and their basic epidemiological characteristics were recorded. Then, blood samples were collected in order to determine the presence of specific $\mathrm{G}$ class antibodies against Ehrlichia canis antigens. An indirect immunofluorescence test manufactured by VMRD, U.S.A., was used. In this study, the seroprevalence of monocytic ehrlichiosis in a population of examined hunting dogs from the region of Vojvodina was $13.79 \%$. This rate is similar to the seroprevalence of monocytic ehrlichiosis in the general population of dogs in Vojvodina.

${ }^{1 \star}$ Author for contact: ale@polj.uns.ac.rs 
Keywords: canine monocytic ehrlichiosis, Ehrlichia canis, hunting dogs, ticks, indirect immunofluorescence test, seroprevalence

\title{
SEROPREVALENCIJA MONOCITNE ERLIHIOZE KOD LOVAČKIH PASA U VOJVODINI
}

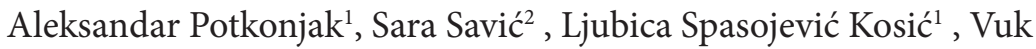 \\ Vračar $^{1}$, Radmila Kudus ${ }^{1}$, Ljiljana Suvajdžić ${ }^{3}$,Nenad Radišić ${ }^{1}$ \\ ${ }^{1}$ Poljoprivredni fakultet, Departman za veterinarsku medicinu, Novi Sad \\ ${ }^{2}$ Naučni institut za veterinarstvo "Novi Sad", Novi Sad \\ ${ }^{3}$ Medicinski fakultet, Departman za farmaciju, Novi Sad
}

\section{Kratak sadržaj}

Monocitna erlihioza pasa je bakterijska, vektorski prenosiva infekcija čiji je uzročnik Ehrlichia canis. Uzročnika oboljenja dominantno prenose krpelji Rhipicephalus sanguineus. Oboljenje ima najveću distribuciju u tropskim i suptropskim regionima, a registrovano je i u mediteranskim zemljama Evrope (Španija, Francuska, Italija, Turska). Umereno kontinentalna klima i prisustvo navedenih vrsta krpelja pogoduje održavanju i širenju monocitne erlihioze u populaciji pasa i u našem regionu. Obzirom da su lovački psi često izloženi ubodu krpelja, u poredjenju sa psima ljubimcima, cilj ovog istraživanja je da pruži uvid u osnovne epidemiološke karakteristike i seroprevalencu monocitne erlihioze lovačkih pasa, kao i da uporedi dobijene rezultate sa podacima o seroprevalenci monocitne erlihioze u opštoj populaciji pasa. U ovom istraživanju je pregledano 58 lovačkih pasa sa područja Vojvodine. Pre uzorkovanja pune venske krvi u cilju izdvajanja krvnih seruma, svi psi su klinički pregledani uz registrovanje osnovnih epidemioloških karakteristika. Za detekciju prisustva specifičnih antitela klase $\mathrm{G}$ na antigen $E$. canis korišćen je test indirektne imunofluorescencije proizvođača VMRD, USA. U ovom istraživanju utvrđeno je da seroprevalencija monocitne erlihioze u populaciji ispitivanih lovačkih pasa sa područja Vojvodine iznosi $13,79 \%$, kao i da je ona slična sa prevalencijom ove infekcije kod opšte populacije pasa na području Vojvodine.

Ključne reči: monocitna erlihioza pasa, Ehrlichia canis, lovački psi, krpelji, test indirektne imunofluorescencije, seroprevalencija 


\section{INTRODUCTION}

Monocytic ehrlichiosis of dogs is a bacterial, vector borne infection caused by Ehrlichia canis. Species of the genus Ehrlichia are obligatory intracytoplazmatic bacteria of the monocyte-macrophage system. Intracellular development of the bacteria is enabled by the reaction of numerous immunoreactive proteins, which to haveplay a key role in the infection, such as adhesives, regulators of the intake of nutrients and inhibitors of proinflammatory cytokines. The causative agent E. canis was first detected in 1935 in Algeria. Afterwards, in 1996, the causative agent of human monocytic ehrlichiosis, E. chaffensis, was found in dogs, broughtwhich gave more significance to this infection from the aspect of public health. The tick Rhipicephalus sanguineus, is the dominant vector for Ehrlichia canis Rhipicephalus sanguineus, but there is evidence on the transmission via Dermacentor variabilis (Johnson et al, 1998), Dermacentor marginatus (Satta et al, 2010), and Ixodes (Wielinga et al, 2006). The disease is most widely distributed in tropical and subtropical regions, but it has also been detected in Mediterranean countries of Europe (Spain, France, Italy, Turkey). Some parts of Spain and Italy are considered endemic regions for ehrlichiosis (Trotz-Williams et al, 2003). Temperate continental climate and presence of aforementioned tick species are predisposing factors for the maintenance and spread of monocytic ehrlichiosis in the population of dogs in our region. During the last few years, the disease has been detected in the neighboring countries including Hungary (Farkas et al, 2014), Romania (Mircean et al, 2012) and Bulgaria (Tsachev et al, 2006). Our previous seroepidemiological study of monocytic ehrlichiosis in the general population of dogs in the region of Vojvodina revealed the seroprevalence rates of $25 \%$ was found, and $16 \%$ obtained by iELISAand $16 \%$ was found in the same population of dogs, by and IIF tests, respectively. (Potkonjak et al, 2013).

The aims of this study was obtaining of basic epidemiological characteristics of monocytic ehrlichiosis, establishing of seroprevalence rate of this infection in hunting dogs and comparing the obtained data with the data from the literature on seroprevalence of monocytic ehrlichiosis in general population of dogs.

\section{MATERIAL AND METHODS}

The research encompassed 58 hunting dogs from the region of Vojvodina. All dogs were clinically examined and all relevant epidemiological data were recorded. Blood samples were taken for blood sera to be isolated. Samples of 
full blood were taken by aseptic puncture of $v$. cephalica antebrachii. Blood sera were separated after centrifugation at $3000 \mathrm{rpm} / \mathrm{min}$ during 10 minutes. Detection of specific antibodies of $\mathrm{G}$ class against antigen of $E$. canis was performed using an indirect immunofluorescence test manufactured by VMRD, USA. Evident presence of the fluorescence of cytoplasmic bodies (morulas) was considered positive finding. The absence of fluorescence was considered negative finding. Serum titer values for $\mathrm{G}$ class immunoglobulins above 1:50 were considered positive finding.

\section{RESULTS}

The examination of 58 hunting dogs' blood sera using the indirect immunofluorescence test 58 blood sera samples from hunting dogs,revealed presence of antibodies of $\mathrm{G}$ class against $E$. canis antigen in 8 samplesE. canis antigene was found, while the remaining 50 samples were seronegative to E. canis. The seroprevalence of monocytic ehrlichiosis in the population of examined hunting dogs from the region of Vojvodina was $13.79 \%$. The positive finding of IF test for E. canis antigen is shown in Figure 1. The age of seropositive dogs was between 1.5 and 6 years, and of the investigated population included the following breeds: Posavic hound, English setter, German hunting terrier, German shorthaired pointer, German wirehaired pointer and brac dachshund. Antibodies of $\mathrm{G}$ class against $E$. canis antigen were found in three females and five males. For the prevention of ectoparasites, the following ectoparasiticides were used in positive dogs: Neostomosan sampoules, Frontline and Ectanon, Taktik and Baygon pulver. The basic epidemiological characteristics found in seropositive dogs to E. canis antigens are shown in Table 1.

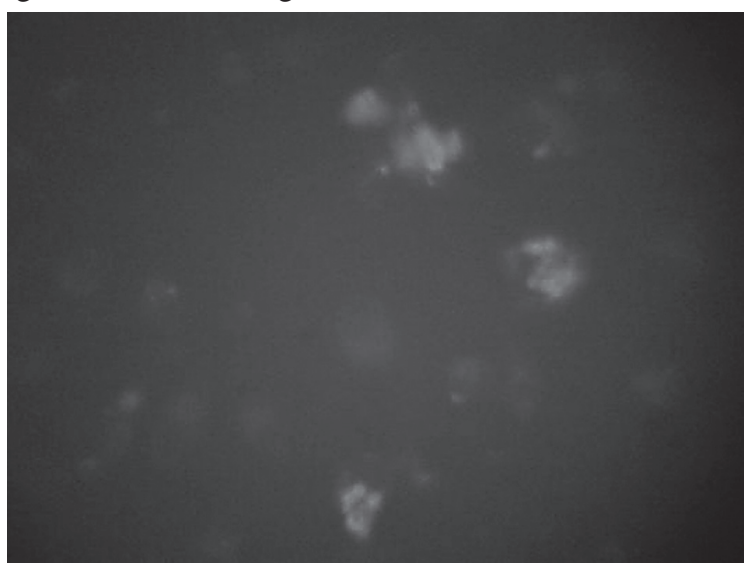

Figure 1. Positive finding of IIF test to antigen of E. canis 
Table 1. Basic epidemiological characteristics found in dogs seropositive to E. canis

\begin{tabular}{|c|c|c|c|c|}
\hline $\begin{array}{c}\text { No of } \\
\text { sample }\end{array}$ & Breed & Gender & Age & $\begin{array}{c}\text { Ectoparasiti- } \\
\text { cides used }\end{array}$ \\
\hline 4. & Posavic hound & Male & 5 years & $\begin{array}{c}\text { Neostomosan } \\
\text { sampoules }\end{array}$ \\
\hline 21. & English setter & Female & 1,5 years & $\begin{array}{c}\text { Frontline and } \\
\text { Ectanon }\end{array}$ \\
\hline 29. & $\begin{array}{c}\text { German } \\
\text { hunting terrier }\end{array}$ & Female & 2,5 years & $\begin{array}{c}\text { Ectanon and } \\
\text { Taktik }\end{array}$ \\
\hline 30. & $\begin{array}{c}\text { German } \\
\text { shorthaired pointer }\end{array}$ & Male & 2 years & $\begin{array}{c}\text { Ectanon and } \\
\text { Taktik }\end{array}$ \\
\hline 32. & $\begin{array}{c}\text { German } \\
\text { wirehaired pointer }\end{array}$ & Male & 2,5 years & Frontline \\
\hline 47. & Brak dachshund & Female & 6 years & \begin{tabular}{c} 
Baygon pulver \\
\hline 53.
\end{tabular} \\
\hline 54. & $\begin{array}{c}\text { German } \\
\text { hunting terrier }\end{array}$ & Male & 4 years & Ectanon \\
\hline hunting terrier & Male & 3 years & Ectanon \\
\hline
\end{tabular}

\section{DISCUSSION}

Because of the climate changes and the geographical spread of the most important vector, Rhipicephalus sanguineus tick, proportional increase in prevalence of monocytic ehrlichiosis in dogs is found. Besides the tropical and subtropical regions, this tick species can also be found in the regions with temperate continental climate, including the region of our country (Christova et al, 2003; Parola et al, 2001).

Hornok et al performed molecular research on the presence of E. canis in ticks from the south region of Hungary and indicated the significance of wild animals as reservoirs of this infection. During the summer 2011, 348 ticks were collected from red foxes (Vulpus vulpus), golden jackals (Canis aureus) and German shepherd. The researchers established that Dermacentor marginatus and Dermacentor reticulatus prefer dogs as hosts, which was not the case before. Dermacentor reticulatus and Ixodes canisuga were most commonly found species in red foxes and golden jackals. In our research, in the nymphs of 
D. marginatus and larvae of I. canisuga the presence of E. canis was established in the nymphs of D. marginatus and larvae of I. canisuga, which indicates potential significance of foxes as a reservoir of infection in the wilderness (Hornok et al, 2013). An experimental transmission of E. canis from grey foxes (Urocyon cinereoargenteus ) to Beale dogs, with Rhipicephalus sanguineus as vector (Amyx et al, 1973)confirmed that foxes could be a potential reservoir in the wilderness. A research performed in Italy in 1995 revealed a seroprevalence rate of $72 \%$ in 154 examined stray dogs from the territory of Imola city in Emilia - Romagna region (Baldelli et al, 1995). During the following decade in Northern Italy, the researchers have found seroprevalence rates of $2.9 \% 8 \%$ in central region and $9.7 \%$ in southern Italy (Solano-Gallego et al, 2006). Seroepidemiological study of E. canis infection in 120 dogs with owners in northern Bulgaria in 2006, showed a total prevalence of $37.5 \%$ whilst the highest prevalence of $60 \%$ was established in a coastal city of Varna. In this research, IF test was used, also (Tsachev et al, 2006). In Former Yugoslav Republic of Macedonia in 2011, sporadic E. canis infection was found in a female of Samoyed breed, 11 years old, using ELISA test. In the same dog, Leishmania infantum was identified by IF test. In this case, the authors state that the coinfection has contributed to the deterioration of clinical findings (Atanaskova et al, 2012). Ina study done in 2012 in Romania, 1146 blood serum samples of dogs were analyzed and an E. canis seroprevalence of $2.1 \%$ was established (Mircean et al, 2012).

In previous seroepidemiological research on monocytic ehrlichiosis in general population of dogs in the region of Vojvodina, seroprevalence rates of $25 \%$ and $16 \%$ were established by iELISA and IF test, respectively (Potkonjak et al, 2013). In this research, the established seroprevalence of monocytic ehrlichiosis in the population of hunting dogs in the region of Vojvodina was $13.79 \%$. This seroprevalence rate for E. canis is in accordance with the data reported by other authors. In spite of general opinion that hunting dogs are more exposed to tick bites, the results of this research demonstrated that the seroprevalence of monocytic ehrlichiosis in hunting dogs was similar to that in the general population of dogs in the same region of Vojvodina. To the purpose of a more efficient monitoring of monocytic ehrlichiosis in dogs in the region of Vojvodina, further and more detailed acarological and epidemiological research is needed in both dog population and the population of wild animals. In the context of the significance of wild animals as reservoirs of infection, we consider the investigation of wild animals and hunting dogs in hunting regions highly important. 


\section{CONCLUSION}

The results obtained in this study demonstrated that seroprevalence of monocytic ehrlichiosis in the population of examined hunting dogs in the region of Vojvodina reached $13.79 \%$. The significance of these results is reflected by the fact that the prevalence is very similar to prevalence of this infectionthat among the general population of dogs in the region of Vojvodina (Potkonjak et al, 2013).

\section{AKNOWLEDGMENT}

This research was financed by a Provincial secretary for science and technological development of AP Vojvodina (name of the project: Research of Lyme disease and other vector borne zoonozes in Vojvodina, project No: 114451-1892/2011) and also by a Ministry of education, science and technological development of Republic of Serbia (name of the project: Monitoring of the health status of wildlife and new biotechnological methods in detection of infectious and zoonotic agents, risk analysis for public health, domestic and wild animals and contamination of environment, project No: TR31084)

\section{REFERENCES}

1. Amyx H., Huxsoll D.: Red and gray foxes-potential reservoir hosts for Ehrlichia canis, Jurnal of Wildlife Diseases, 9, 1:47-50, 1973.

2. Atanaskova E., Kocevski Z., Nikolovski G., Stefanovska J.: Case report of canine co-infection with Leishmania infantum and Ehrlichia canis, Mac. Vet. Rev., 34, 1: 19 - 24, 2011.

3. Baldelli R., Di Francesco A., Fioravanti L., Borello B.: Ehrlichiosis canina. Indagine sieroepidemiologica in un canile dell'Emilia-Romanga, Obiettivi e Documenti Veterinari, 16, 61-63, 1995.

4. Christova I., Van De Pol J., Fioravanti L., Schouls L.: Identification of Borrelia burgdoferi sensu lato, Anaplasma and Ehrlichia species, and spotted fever group Rickettsiae in ticks from Southeastern Europe, Europen Jurnal of Clinical Microbiology and Infectious Disease, 22, 9, 535-542, 2003.

5. Farkas R., Gyurkovszky M., Lukács Z., Aladics B., Solzmosi N.: Seroprevalence of some vector-borne infections of dogs in Hungary, Vector Borne Zoonotic Diseases, 14, 4, 256-60, 2014.

6. Hornok S,. Fuente J., Horváth G., Fernández de Mera I., Wijnveld M., Farkas R., Jongejan F.: Molecular evidence of Ehrlichia canis and Rickettsia 
massiliae in Ixodid ticks of carnivores from south Hungary, Acta Veterinaria Hungarica, 61, 1, 42-50, 2013.

7. Johnson E., Ewing S., Barker R., Fox J., Crow D., Kocan K.: Experimental transmission of Ehrlichia canis (Rickettsiales: Ehrlichieae) by Dermacentor variabilis (Acari: Ixodidae), Vet Parasitol, 74, 2-4, 277-88, 1998.

8. Mircean V., Dumitrache M., Györke A., Pantchev N., Jodies R., Mihalca A., Cozma V.: Seroprevalence and Geographic Distribution of Dirofilaria immitis and Tick-Borne Infections (Anaplasma phagocytophilum, Borrelia burgdorferi sensu lato, and Ehrlichia canis) in Dogs from Romania, Vector-Borne and Zoonotic Diseases, 12, 7, 595-604, 2012.

9. Parola P., Raoult D.: Ticks and tickborne bacterial diseases in humans: an emerging infectious threat, Clinical Infectious Diseases, 32, 6, 897-928, 2001.

10. Potkonjak A., Savić S., Jurišić A., Petrović A., Suvajdžić Lj., Lako B., Milošević N., Novaković Z.: Seroepidemiological research of canine monocytic ehrlichiosis in the Autonomous Province of Vojvodina, Serbia, Acta Scientiae Veterinariae, 41, 1106, 2013.

11. Satta G., Chisu V., Cabras P., Foisand F., Masala G. : Pathogens and symbionts in ticks: a survey on tick species distribution and presence of ticktransmitted micro-organisms in Sardinia, Italy, Journal of Medical Microbiology, 60, 1, 63-8, 2010.

12. Solano-Gallego L., Trotta M., Razia L., Furlanello T., Caldin M.: Molecular survey of Ehrlichia canis and Anaplasma phagocytophilum from blood of dogs in Italy, Annals of the New York Academy of Sciences, 1078, 515-518, 2006.

13. Trotz-Williams L.A., Trees A.J.: Systematic review of the distribution of the major vector-borne parasitic infections in dogs and cats in Europe, Veterinary Record, 152, 4, 97-105, 2003.

14. Tsachev I., Papadogiannakis I., Kontos V., Zarkov I., Petrov V., Pelagic V.: Seroprevalence of Ehrlichia canis infection among privately-owned dogs in northern Bulgaria, Hellenic Veterinary Medical Society, 57, 3, 206-216, 2006.

15. Wielinga P., Gaasenbeek C., Fonville M., de Boer A., de Vries A., Dimmers W., Akkerhuis Op Jagers G., Schouls L., Borgsteede F., van der Giessen J.: Longitudinal analysis of tick densities and Borrelia, Anaplasma, and Ehrlichia infections of Ixodes ricinus ticks in different habitat areas in The Netherlands, Applied and Environmental Microbiology, 72, 12, 7594-601, 2006. 